Pace University

DigitalCommons@Pace

$5-18-2003$

\title{
Honorary Degree Citation, Sonia Sotomayor, Doctor of Laws, May 18,2003
}

Pace University School of Law

Follow this and additional works at: https://digitalcommons.pace.edu/lawfaculty

Part of the Law Commons

\section{Recommended Citation}

Pace University School of Law, "Honorary Degree Citation, Sonia Sotomayor, Doctor of Laws, May 18, 2003" (2003). Pace Law Faculty Publications. 565.

https://digitalcommons.pace.edu/lawfaculty/565

This Article is brought to you for free and open access by the School of Law at DigitalCommons@Pace. It has been accepted for inclusion in Pace Law Faculty Publications by an authorized administrator of DigitalCommons@Pace. For more information, please contact dheller2@law.pace.edu. 


\title{
HONORARY DEGREE CITATION
}

\author{
SONIA SOTOMAYOR
}

\section{DOCTOR OF LAWS}

If ever there were a role model of aspiration, discipline, commitment, intellectual prowess and integrity, it is you, Sonia Sotomayor. The nation, in general, and the people of the Second Judicial Circuit, in particular, benefit from your solid judicial experience. Even in our postmodern, deconstructionist society when the reality of impartiality seems, at times, illusory, you have proven that you maintain the rule of law, uphold the U.S. Constitution, and administer justice impartially and fairly according to law. Your progressively stellar career is evidence of your hard work and intelligence as well as your dedication to public service.

You grew up in the Bronx, New York. In 1976, you earned your B.A. from Princeton University and graduated summa cum laude. You also won honorable mention for your senior thesis in Latin American Studies. In 1979, you earned your J.D. from Yale Law School. During your years at Yale, you served as editor of the Yale Law Journal and as managing editor of the Yale Studies in World Public Order.

You began your legal career in 1979 as an assistant district attorney in the New York County District Attorney's Office. As an A.D.A., you were responsible for the investigation and evaluation of felony cases, grand jury presentations, pretrial motion practice, bench and jury trials, appellate briefs and arguments. From 1984 to 1992, you practiced law, as an associate and later as a partner, with the firm of Pavia \& Harcourt in New York City. At Pavia \& Harcourt, you handled international commercial litigation, including the drafting of pleadings, pretrial discovery, depositions and trials. You also gained extensive experience in the arbitration of commercial and commodity export trading cases.

From 1992 to 1998, you presided as a U.S. district judge for the Southern District of New York. Your 1992 appointment, for which President Bush nominated you, made you the first Hispanic woman to serve on a federal bench. Since 1998, you have been presiding as a U.S. circuit judge for the U.S. Court of Appeals for the Second Circuit. The Second Judicial Circuit consists of all federal courts within the states of New York, Connecticut and Vermont, including the Court of Appeals for the Second Circuit and the respective district and bankruptcy courts. President Clinton nominated you for that judgeship. You have decided hundreds of cases, including matters of copyright law in the context of new media, and rulings in favor of public access to private information and in defense of religious freedom.

You are the recipient of several awards, including Honorary Degrees from Brooklyn Law School, Princeton University and Herbert H. Lehman College. Your continued commitment to legal education is evidenced by your work as a lecturer in law at Columbia Law School, since 1999, and an adjunct professor at New York University School of Law, since 1998. You hold memberships in the American Bar Association, the Hispanic Bar Association, the Association of Judges of Hispanic Heritage, the Puerto Rican Bar Association, the New York Women's Bar Association and the American Philosophical Society.

Because of your brilliant achievements, exceptional judicial efforts and dedication to public service, Pace University is very proud to confer upon you the degree of Doctor of Laws, honoris causa, with all the rights and privileges pertaining thereunto. 